\title{
The Science of Speleology
}

edited by T. D. Ford and C. H. D. Cullingford August 1976, xvi $+600 \mathrm{pp}$. $£ 14.00 / \$ 29.50 \quad 0.12 .262550 .1$

Each chapter of this remarkable book covers a different scientific discipline in its particular application to speleology. The natural phenomena of caves are described, and the methods of investigation considered in detail. Examples are drawn from caves throughout the world, providing the reader with a rich and varied range of cave forms and their contents. The contributors, all recognized authorities, are also experienced cavers, and provide sound practical guidance to field study.

The fascination of caves extends far beyond the confines of the research laboratory, and this book will be a stimulating source of information for all those with a general interest in caving, as well as those engaged in detailed study.

\section{The Evolution of the Crystalline Rocks}

\section{edited by $D$. K. Bailey and R. Macdonald November/December 1976 xii +484 pp. $£ 16.00 / \$ 35.00 \quad 0.12 .073450 .8$}

This book illuminates the rationale of experimental petrology and highlights the major developments in key areas. Enormous advances have been made in this field over the last few decades, widening the gap between the experimentalist and the geologist. This book seeks to bridge that gap.
Each of the contributors brings the special combination of experimental and geological experience to this topic, and stresses the geological applications to a major group of rocks. The result is a series of perspectives, which reveal the limitations as well as the great achievements of experimental studies applied to rocks.

\section{Academic Press}

\section{London New York San Francisco}

A Subsidiary of Harcourt Brace Jovanovich, Publishers

24-28 Oval Road, London NW1, England 111 Fifth Avenue, New York, NY 10003, U.S.A.

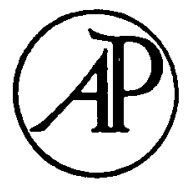

Australian Office: PO Box 300, North Ryde, NSW 2113, Australia 


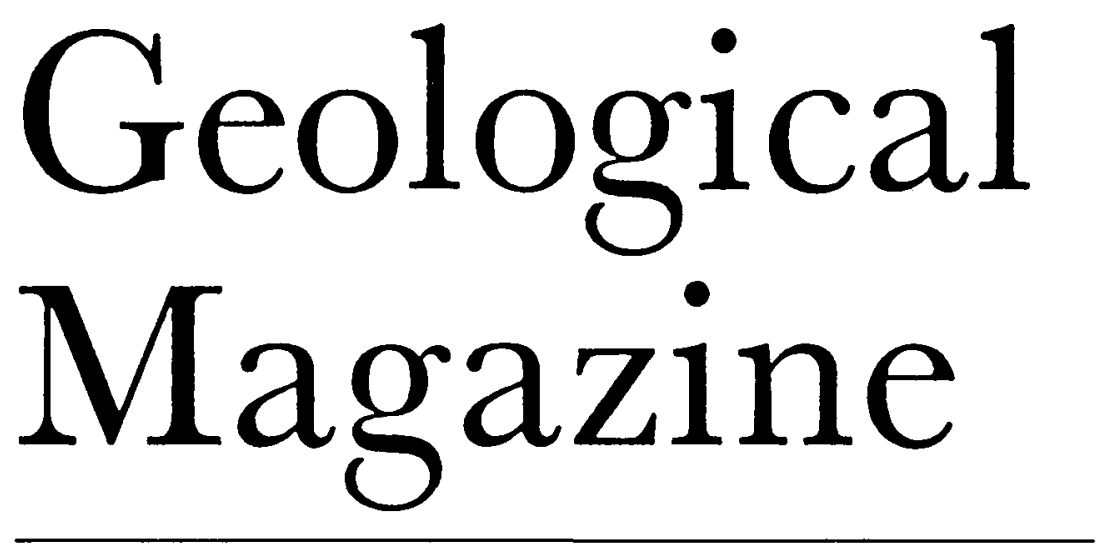

with which is incorporated

\section{The Geologist}

founded in 1864 by the late DR HENRY WOODWARD, F.R.S.

Edited by W. B. HARLAND, M.A.

C. P. HUGHES, M.A.

and G. A. CHINNER, PH.D.

assisted by MRS M. J. MASON

Associate editors

SIR KINGSLEY DUNHAM, D.SC., F.R.S.

MR N. L. FALCON, M.A., F.R.S.

PROFESSOR LEONARD HAWKES, D.SC., F.R.S.

SIR PETER KENT, D.SC., F.R.S.

DR S. R. NOCKOLDS, PH.D., F.R.S.

PROFESSOR F. W. SHOTTON, M.B.E., M.A., SC.D., F.R.S.

SIR JAMES STUBBLEFIELD, D.SC., F.R.S.

Volume I 3 of Whole Series

January-December 1976

CAMBRIDGE UNIVERSITY PRESS

GAMBRIDGE - LONDON - NEW YORK 


$$
\text { PUBLISHED BY }
$$

THE SYNDICS OF THE CAMBRIDGE UNIVERSITY PRESS

The Pitt Building, Trumpington Street, Cambridge CB2 1RP

Bentley House, P.O. Box 92, 200 Euston Road, London NW1 2DB

32 East 57th Street, New York, N.Y. 10022

(c) Cambridge University Press 1976

Pagination and dates of publication of issues in this volume

Number 1: pp. 1-96 January 1976

2: pp. 97-192 March 1976

3: pp. 193-304 May 1976

4: pp. 305-400 July 1976

5: pp. 401-496 September 1976

6: pp. 497-592 December 1976 


\section{Contents}

\section{ARTICLES}

(Figures in bold type denote number of issue)

AGUIRRE, L.

Structural evolution of the Northernmost Andes, Colombia, 5, 475

ALI, M. T.

The significance of a mid-Cretaceous cobble conglomerate, Beer District, South Devon, 2, 151

BENNETT, M. C.

The ultramafic-mafic complex at North Cape, northernmost NewZealand, 1, 61

BOWES, D. R., HOPGOOD, A. M. \& PIDGEON, R. T.

Source ages of zircons in an Archaean quartzite, Rona, Inner Hebrides, Scotland, 6, 545

BRERETON, N. R., HOOKER, P. J. \& MILLER, J. A.

Some conventional potassium-argon and ${ }^{40} \mathrm{Ar} /{ }^{39} \mathrm{Ar}$ age studies of glauconite (Plate 1), 4, 329

BRUNSDEN, D., DOORNKAMP, J. C., GREEN, C. P. \& JONES, D. K. C.

Tertiary and Cretaceous sediments in solution pipes in the Devonian Limestone of South Devon, England, 5, 441

CAMERON, W. E.

Coexisting sillimanite and mullite (Plates 1-2), 6, 497

CHALLINOR, $\mathrm{J}$.

The 'Precambrian' in Cambria, 5, 449

CRIMES, T. P. \& MARCOS, A.

Trilobite traces and the age of the lowest part of the Ordovician reference section for N.W. Spain (Plates 1-2), 4, 349

CROWTHER, P. R. \& JENKINS, C. J.

Retiolitids from the Llanvirn and Darriwillian (Plate 1), 3, 277

DESMET, A. P.

Evidence of co-genesis of the Troodos Lavas, Cyprus, 2, 165

DE WIT, M. J.

A note on the origin of syntectonic porphyroblasts and their inclusion fabrics

(Plates 1-3), 4, 383

DUNCAN, A. M.

Pyroclastic flow deposits in the Adrano area of Mount Etna, Sicily, 4, 357

DURRANCE, E. M.

A gravity survey of Islay, Scotland, 3, 251

FITCH, F. J., MILLER, J. A. \& HOOKER, P. J.

Single whole rock $\mathrm{K}-\mathrm{Ar}$ isochrons, 1,1 
FRENCH, W. J.

Rock composition, density and a variation diagram, 4, 371

FREUND, R. \& MERZER, A. M.

The formation of rift valleys and their zigzag fault patterns (Plate 1), 6, 561

FUNNELL, B. M.

Geological Hazards, 5, 487

FURNISH, W. M., GLENISTER, B. F., KUMMEJ,, B., SPINOSA, C., SWEET, W. \& TEICHERT, C.

Reinterpretation of ceratitic ammonoids from the Greville Formation, New Zealand, 1, 39

HAIDUTOV, I. S.

A greenstone belt-basement relationship in the Tanganyika shield, 1, 53

HUGHES, N. F., HARLAND, W. B. \& SMITH, D. G.

Preservation and abundance of palynomorphs in Svalbard, 3, 233

JULL, R. K.

Review of some species of Favistina', Nyctopora, and Calapoecia (Ordovician corals from North America) (Plates 1-4), 5, 457

KNOX, G. J.

The early Tertiary deep-water sandstones near San Sebastian, Spain; some aspects of diagenesis (Plates 1-4), 4, 341

LEITCH, E. C.

Emplacement of an epizonal granodiorite pluton $\lambda$ by vertical block elevation, 6, 553

MAcRAE, N. D., GRANT, M. \& KULLERUD, G.

A note on the sulphurization of Fe--Tremolite (Plate 1), 6, 575

MATTHEWS, D. W.

Post-cumulus disruption of the Lilloise Intrusion, Eas: Greenland (Plate 1), 3, 287

MAW, U BA, SAN, U BO, ROSS, J. R. P. \& CIOCHON, R. L.

The Ordovician Bryozoan (Ectoproct) Diplotrypa from Central Burma (Plate 1), 6, 515

MCCLAY, K. R. \& CAMPBELL, I. H.

The structure and shape of the Jimberlana Intrusion, Western Australia, as indicated by an investigation of the Bronzite Complex, 2, 129

MITCHELL, J. G., JONES, E. J. W. \& JONES, G. T.

The composition and age of basalts dredged from the Blackstones igneous centre, western Scotland, 6, 525

NAMI, M.

An exhumed Jurassic meander belt from Yorkshire, Er.gland (Plates 1-2), 1, 47

PAUL, C. R. C.

Ordovician echinoderms from Greenland, 1, 29 
PICKERILL, R. K.

Vermiforichnus borings from the Ordovician of central Wales, 2, 159

PLIMER, I. R.

Garnet-biotite relationships in high grade metamorphic rocks at Broken Hill, Australia, 3, 263

REID, R. E. H.

Late Cretaceous climatic trends, faunas, and hydrography in Britain and Ireland, 2, 115

ROBERTS, D. E.

Cleavage formation in the Skiddaw Slates of the northern Lake District, England (Plates 1-2), 4, 377

ROCK, N. M. S.

The role of $\mathrm{CO}_{2}$ in alkali rock genesis, 2, 97

ROMANO, M.

The trilobite genus Placoparia from the Ordovician of the Valongo area, North Portugal (Plate 1), 1, 11

ROOBOL, M. J.

Post-eruptive mechanical sorting of pyroclastic material - an example from Jamaica (Plates 1-2), 5, 429

SCRUTTON, C. T., HORSFIELD, W. T. \& HARLAND, W. B.

Silurian fossils from western Spitsbergen, 6, 519

SHOTTON, F. W.

Amplification of the Wolstonian Stage of the British Pleistocene, 3, 241

SMITH, D. G., HARLAND, W. B., HUGHES, N. F. \& PICKTON, C. A. G. The geology of Kong Karls Land, Svalbard, 3, 193

STUART, A. J. \& WEST, R. G.

Late Cromerian Fauna and Flora at Ostend, Norfolk, 5, 469

SUÁREZ, M. \& PETTIGREW, T. H.

An Upper Mesozoic island-arc-back-arc system in the southern Andes and South Georgia, 4, 305

TAMMEMAGI, H. Y.

Radioelement concentrations in British Tertiary Granites, 3, 271

THAKUR, V. C. \& TANDON, S. K.

Significance of pebble and mineral lineation in the Chamba syncline of Punjab Himalaya, Himachal Pradesh, India, 2, 141

TUCKER, M. E.

Quartz replaced anhydrite nodules ('British Diamonds') from the Triassic of the Bristol District (Plates 1-2), 6, 569

TURNER, P., TARLING, D. H., ARCHER, R. \& DONOVAN, R. N.

A palaeomagnetic argument concerning post-Devonian displacement along the Great Glen Fault, 4, 365 
WATERHOUSE, J. B. \& BONHAM-CARTER, G.

Range, proportionate representation, and demise of brachiopod families through Permian Period, 5, 401

WEAVER, J. D.

Seismically-induced load structures in the basal Coal Measures, South Wales, 6,535

WILLIAMS, D. M.

Clastic dykes from the Precambrian Porsangerfjord Group, North Norway (Plates 1-2), 2, 169

WILLIAMS, H. R.

An erosional structure in a layered dolerite dyke, West Greenland (Plates 1-2), 1,77

\section{CORRESPONDENCE}

BATE, R. H. New name for Rhadinocythere Bate, 1975, 5, 489

O'CONNOR, P. J. Strontium isotope ratios of some acid rocks from Mull and and Arran, Scotland, 4, 389

Applied Geophysics, 5, 492

\section{REVIEWS}

Carbonate Facies in Geologic History, 6, 584

Compaction of Coarse-grained Sediments, 2, 180

Coupes et Cartes géologiques, 4, 396

Death Valley. Geology, Ecology, Archaeology, 6, 585

Deposits of Fossil Fuels, 2, 178

Devonian Stratigraphy of the Hudson Platform, 6, 589

The Earth's Core, 4, 395

Encounter with the Earth, 1, 91

Encyclopedia of Earth Sciences. Vol. VIII. The Encyclopeclia of World Regional Geology; Part 1: Western Hemisphere (including Antarctica and Australasia), 5,493

Evolution and Diagenesis of Quaternary Carbonate sequences, Shark Bay, Western Australia, 1, 83

Evolution and Extinction Rate Controls, 1, 88

Evolution and Morphology of the Trilobita, Trilobitoidea and Merostomata, 6, 581

Focus on Environmental Geology, 6, 586

Fossils (2nd edn), 6, 585

Gebirgemechanik im Salz. Struktur und Gebirgsbewegungen, 4, 393

Geological Outline of Sardinia, 6, 587

The Geological Retrieval and Synopsis Program, 3, 301

The Geological Time Table, 3rd edition, 2, 182

Geology Explained: The Peak District, 6, 586 
The Geology of Central New Zealand, 1, 87

The Geology of Continental Margins, 1, 89

Geology of the Oman Mountains, 6, 582

Glacial and Periglacial Geomorphology (2nd edn), volumes 1 and 2, 6, 580

Gypsum and Anhydrite, 4, 394

The Hot-Blooded Dinosaurs, 3, 297

Ice Ages: Ancient and Modern, 1, 87

Identification Tables for Minerals in Thin Sections, 1, 91

Introduction to Geology. Volume 2. Earth History, 2, 179

Introduction to Marine Geology and Geomorphology, 4, 397

Introduction to Physical and Biological Oceanography, 4, 397

An Introduction to Sedimentology, 5, 491

Investigations of Lower Paleozoic geology, 4, 396

Jurassic and lower Cretaceous paleogeography and depositional tectonics of

Porcupine Plateau, adjacent areas of northern Yukon and those of Mackenzie

District, 2, 179

Lehrbuch der Allgemeinen Geologie, 1, 84

The Logic of Geological Maps, 3, 300

Lower and lower Middle Devonian rugose corals of the Central Great Basin, 2, 177

A Manual of Scientific Enquiry prepared for the use of Officers in Her Majesty's Navy; and Travellers in General, 4, 392

Marine Geology and Oceanography of the Arctic Seas, 1, 85

Metamorphic Processes. Reactions and Microstructure Development, 4, 394

Methods of Treatment of Unstable Ground, 2, 182

Middle Devonian rugose corals of the Central Great Basin, 2, 177

Miospores and microplankton from Aptian-Albian rocks along Horton River,

District of Mackenzie, 6, 590

Normapolles pollen from the Mississippi embayment, 6, 589

Norsk Polarinstitutt. 1976. Årbok 1974, 5, 492

The Ordovician Trilobites of Spitsbergen, 2, 184

Ore Deposits, 4, 393

Palynologic analyses of Upper Mesozoic and Cenozoic rocks of the Grand Banks, Atlantic Continental Margin, 4, 398

Petrogenesis of Metamorphic Rocks, 1, 90

Petroleum geology of Naval Petroleum Reserve No 1, Elk Hills, Kern County, California, 5, 491

Physical Aspects of Natural Catastrophes, 1, 91

The Rockhound's Handbook, 6, 579

The Rotation of the Earth, 2, 183

Sedimentation Models and Quantitative Stratigraphy, 3, 298

Sediments and Sedimentary Rocks, 1, 86

Silurian-Lower Devonian Conodont sequence in the Roberts Mountains Formation of Central Nevada, 1, 85

Silurian rugose corals of the central and southwest Great Basin, 2, 177

Structural style influenced by lithofacies, Rocky Mountain Main Ranges,

Alberta - British Columbia, 6, 587 
The Structure of the Alps, 3, 300

The Structure of the Earth's Crust, 6, 579

Tectonic Evolution of the Northern Apennines, 6, 587

Tectonic studies of the Berkshire Massif, western Massachusetts, Connecticut and Vermont, 2, 184

Tertiary Faunas. Volume 1: The Composition of Tertiary Faunas. Volume 2:

The Sequence of Tertiary Faunas, 2, 182

Trace Element Analysis, 4, 393

Trek of the Oil Finders: A History of Exploration for F'etroleum, 2, 181

Trilobites. A Photographic Atlas, 2, 184

Upper Silurian? to Middle Devonian Spores of the Moose River Basin, Ontario, 6, 588

Volcanoes of the Earth, Moon and Mars, 6, 583

Publications Received

Lists appear beginning pages 1,$93 ; 2,185 ; 3,302 ; 4,399 ; 5,495 ; 6,591$ 


\section{Index}

to Authors, key words in titles and to new taxa in Volume 113;

(R) indicates Review

Aguirre, L. Structural evolution of the Northernmost Andes, Colombia, 475

Aitkenicythere, 489

Alberta, Rocky Mountain Main Ranges (R), 587

Ali, M. T. The significance of a mid-Cretaceous cobble conglomerate, Beer

District, south Devon, 151

Alkali rock genesis, 97

Allgemeinen Geologie (R), 84

Alps (R), 300

Ammonoids, ceratitic, 39

Andes, northernmost, 475; southern, 305

Anhydrite (R), 394; nodules, 569

Apennines, Northern (R), 587

Aptian-Albian (R), 590

${ }^{10} \mathrm{Ar} /{ }^{30} \mathrm{Ar}$ age, 329

Archaean quartzite, 545

Archaeology, Death Valley (R), 585

Archer, R., Turner, P., Tarling, D. H. \& Donovan, R. N. A palaeomagnetic argument concerning post-Devonian displacement along the Great Glen Fault, 365

Arctic Seas (R), 85

Arran, 389

Australia, Broken Hill, 263

Back-arc, 305

Basalts, western Scotland, 525

Basement, Tanganyika shield, 53

Bate, R. H. New name for Rhadinocythere Bate, 1975, 489

Beer District, south Devon, 151

Bennett, M. C. The ultramafic-mafic complex at North Cape, northernmost New Zealand, 61

Berkshire Massif, U.S.A. (R), 184

Blackstones igneous centre, western Scotland, 525

Bonham-Carter, G. \& Waterhouse, J. B. Range, proportionate representation, and demise of brachiopod families through Permian Period, 401

Bowes, D. R., Hopgood, A. M. \& Pidgeon, R. T. Source ages of zircons in an Archaean quartzite, Rona, Inner Hebrides, Scotland, 545

Brachiopod families, 401

Brereton, N. R., Hooker, P. J. \& Miller, J. A. Some conventional potassiumargon and ${ }^{40} \mathrm{Ar} /{ }^{38} \mathrm{Ar}$ age studies of glauconite, 329

'Bristol Diamonds', 569 
Britain, 115

British Columbia, Rocky Mountain Main Ranges (R), 5:37

British Tertiary Granites, 271

Broken Hill, Australia, 263

Bronzite Complex, 129

Brunsden, D., Doornkamp, J. C., Green, C. P. \& Jones, D. K. C. Tertiary and

Cretaceous sediments in solution pipes in the Devonian Limestone of South Devon, England, 441

Bryozoan, Ordovician, 515

Burma, Central, 515

Calapoecia, 457

Cambria, 449

Cameron, W. E. Coexisting sillimanite and mullite, 497

Campbell, I. H. \& McClay, K. R. The structure and shape of the Jimberlana Intrusion, Western Australia, as indicated by an investigation of the Bronzite Complex, 129

?Carabocrinus sp., 35

Carbonate Facies (R), 584

Cartes géologiques (R), 396

Central Nevada, Silurian - Lower Devonian (R), 85

Cenozoic, Grand Banks (R), 398

Challinor, J., The 'Precambrian' in Cambria, 449

Chamba syncline, 141

Cheirocystella sp., 33

Ciochon, R. L., Maw, U Ba, San, U Bo \& Ross, J. R.P. The Ordovician Bryozoan (Ectoproct) Diplotrypa from Central Burma, 515

Cleavage, 377

Climatic trends, 115

Coal Measures, South Wales, 535

Coarse-grained Sediments (R), 180

Co-genesis, 165

Colombia, 475

Conodont, Central Nevada (R), 85

Continental Margins (R), 89

Corals, Devonian (R), 177; Ordovician, 457; Silurian (R), 177

Cretaceous, Late, 115; Mid, 151; paleogeography (R), 179; sediments, 441

Crimes, T. P. \& Marcos, A. Trilobite traces and the age of the lowest part of the Ordovician reference section for N.W. Spain, 349

Cromerian, 469

Crowther, P. R. \& Jenkins, C. J. Retiolitids from the Llanvirn and Darriwillian, 277

Cyprus, 165

Darriwillian, 277

Death Valley (R), 585

Desmet, A. P. Evidence of co-genesis of the Troodos Lavas, Cyprus, 165 
Devon, mid-Cretaceous, 151; South, Tertiary and Cretaceous, 441

Devonian, Great Basin (R), 177; Hudson Platform (R), 589; Limestone, 441

De Wit, M. J. A note on the origin of syntectonic porphyroblasts and their inclusion fabrics, 383

Dinosaurs (R), 297

Diplotrypa, 515

Dolerite, 77

Donovan, R. N., Turner, P., Tarling, D. H. \& Archer, R. A palaeomagnetic argument concerning post-Devonian displacement along the Great Glen Fault, 365

Doornkamp, J. C., Brunsden, D., Green, C. P. \& Jones, D. K. C. Tertiary and Cretaceous sediments in solution pipes in the Devonian Limestone of South Devon, England, 441

Duncan, A. M. Pyroclastic flow deposits in the Adrano area of Mount Etna, Sicily, 357

Durrance, E. M. A gravity survey of Islay, Scotland, 251

Dyke, layered dolerite, 77

Dykes, clastic, 169

Earth (R), 91; History (R), 179; Rotation (R), 183; Sciences, Western Hemisphere (R), 493; Volcanoes (R), 583

Earth's Core (R), 395; Crust (R), 579

Echinoderms, 29

Ecology, Death Valley (R), 585

England, Jurassic, 47

Environmental Geology (R), 586

Evolution (R), 88

Extinction (R), 88

Facies, Carbonate (R), 584

Fault patterns, 561

Faunas, Late Cretaceous, 115; Tertiary (R), 182

Favistina, 457

Fe-Tremolite, 575

Fitch, F. J., Miller, J. A. \& Hooker, P. J. Single whole rock K-Ar isochrons, 1 Fossil Fuels (R), 178

Fossils (R), 585

French, W. J. Rock composition, density and a variation diagram, 371

Freund, R. \& Merzer, A. M. The formation of rift valleys and their zigzag fault patterns, 561

Funnell, B. M. Geological Hazards, 487

Furnish, W. M., Glenister, B. F., Kummel, B., Spinosa, C., Sweet, W. \& Teichert, C. Reinterpretation of ceratitic ammonoids from the Greville Formation, New Zealand, 39

Garnet-biotite, 263

Geological, Hazards, 487; Maps (R), 300; Retrieval and Synopsis Program (R), 301; Time Table (R), 182 
Geology, Death Valley (R), 585; Introduction (R), 179

Geomorphology (R), 580; Introduction (R), 397

Geophysics, Applied (R), 492

Georgia, South, 305

Glacial Geomorphology (R), 580

Glauconite, 329

Glenister, B. F., Furnish, W. M., Kummel, B., Spinosa, C., Sweet, W. \& Teichert, C. Reinterpretation of ceratitic ammonoids from the Greville Formation, New Zealand, 39

Glyptocystites groenlandicus sp.nov., 30

Granites, Tertiary, 271

Granodiorite, emplacement of, 553

Grant, M., MacRae, N. D. \& Kullerud, G. A note on the sulphurization of Fe-Tremolite, 575

Gravity survey, 251

Great Basin, rugose corals (R), 177; Silurian (R), 177

Great Glen Fault, 365

Green, C. P., Brunsden, D., Doornkamp, J. C. \& Jones, D. K. C. Tertiary and Cretaceous sediments in solution pipes in the Devonian Limestone of South Devon, England, 441

Greenland, East, 287; Ordovician, 29; West, 77

Greenstone belt, 53

Greville Formation, 39

Ground Unstable (R), 182

Gypsum (R), 394

Haidutov, I. S. A greenstone belt-basement relationship in the Tanganyika shield, 53

Handbook, Rockhound's (R), 579

Harland, W. B., Hughes, N. F. \& Srnith, D. G. Preservation and abundance of palynomorphs in Svalbard, 233

Harland, W. B., Scrutton, C. T. \& Horsfield, W. T. Silurian fossils from western Spitsbergen, 519

Harland, W. B., Smith, D. G., Hughes, N. F. \& Pickton, C. A. G. The geology of Kong Karls Land, Svalbard, 193

Hebrides, Inner, 545

Himalaya, 141

Hooker, P. J., Brereton, N. R. \& Miller, J. A. Some conventional potassiumargon and ${ }^{40} \mathrm{Ar} /{ }^{39} \mathrm{Ar}$ age studies of glauconite, 329

Hooker, P. J., Fitch, F. J. \& Miller, J. A. Single whole: rock K-Ar isochrons, 1 Hopgood, A. M., Bowes, D. R. \& Pidgeon, R. T. Sou:ce ages of zircons in an Archaean quartzite, Rona, Inner Hebrides, Scotland, 545

Horsfield, W. T., Scrutton, C. T. \& Harland, W. B. Silırian fossils from western Spitsbergen, 519

Hudson Platform, Devonian (R), 589

Hughes, N. F., Harland, W. B. \& Smith, D. G. Preservation and abundance of palynomorphs in Svalbard, 233 
Hughes, N. F., Smith, D. G., Harland, W. B., Pickton, C. A. G. The geology of Kong Karls Land, Svalbard, 193

Hydrography, Late Cretaceous, 115

Ice Ages (R), 87

Inclusion fabrics, 383

India, 141

Ireland, 115

Island-arc, 305

Islay, Scotland, 251

Isochrons, $\mathrm{K}-\mathrm{Ar}, 1$

Jamaica, 429

Jenkins, C. J. \& Crowther, P. R. Retiolitids from the Llanvirn and Darriwillian, 277

Jimberlana Intrusion, 129

Jones, D. K. C., Brunsden, D., Doornkamp, J. C. \& Green, C. P. Tertiary and Cretaceous sediments in solution pipes in the Devonian Limestone of South Devon, England, 441

Jones, E. J. W., Mitchell, J. G. \& Jones, G. T. The composition and age of basalts dredged from the Blackstones igneous centre, western Scotland, 525

Jones, G. T., Mitchell, J. G. \& Jones, E. J. W. The composition and age of basalts dredged from the Blackstones igneous centre, western Scotland, 525

Jull, R. K. Review of some species of Favistina, Nyctopora, and Calapoecia (Ordovician corals from North America), 457

Jurassic, 47; Porcupine Plateau (R), 179

$\mathrm{K}-\mathrm{Ar}$ isochrons, 1

Knox, G. J. The early Tertiary deep-water sandstones near San Sebastian, Spain; some aspects of diagenesis, 341

Kong Karls Land, 193

Kullerud, G., MacRae, N. D. \& Grant, M. A note on the sulphurization of Fe-Tremolite, 575

Kummel, B., Furnish, W. M., Glenister, B. F., Spinosa, C., Sweet, W. \& Teichert, C. Reinterpretation of ceratitic ammonoids from the Greville Formation, New Zealand, 39

Lake District, 377

Leitch, E. C. Emplacement of an epizonal granodiorite pluton $\lambda$ by vertical block elevation, 553

Lilloise Intrusion, 287

Limestone, Devonian, 441

Llanvirn, 277

Load structures, seismically-induced, 535

Lower Devonian, Central Nevada (R), 85

MacRae, N. D., Grant, M. \& Kullerud, G. A note on the sulphurization of Fe-Tremolite, 575

Macrocystella sp.nov., 33 
Mafic Complex, New Zealand, 61

Marcos, A. \& Crimes, T. P. Trilobite traces and the age of the lowest part of the Ordovician reference section for N.W. Spain, 349

Marine Geology, Arctic Seas (R), 85; Introduction (R), 397

Mars, Volcanoes (R), 583

Matthews, D. W. Post-cumulus disruption of the Lilloise Intrusion, East Greenland, 287

Maw, U Ba, San, U Bo, Ross, J. R. P. \& Ciochon, R. L. The Ordovician Bryozoan (Ectoproct) Diplotrypa from Central Burnia, 515

McClay, K. R. \& Campbell, I. H. The structure and shape of the Jimberlana Intrusion, Western Australia, as indicated by an. investigation of the Bronzite Complex, 129

Merostomata (R), 581

Merzer, A. M. \& Freund, R. The formation of rift valleys and their zigzag fault patterns, 561

Mesozoic, Grand Banks (R), 398; Upper, 305

Metamorphic Processes (R), 394; Rocks (R), 90; rocks, high grade, 263

Microplankton (R), 590

Miller, J. A., Brereton, N. R., \& Hooker, P. J. Some conventional potassiumargon and ${ }^{40} \mathrm{Ar} /{ }^{39} \mathrm{Ar}$ age studies of glauconite, 329

Miller, J. A., Fitch, F. J. \& Hooker, P. J. Single whole rock K-Ar isochrons, 1

Mineral lineation, 141

Minerals, Identification Tables (R), 91

Miospores (R), 590

Mississippi embayment (R), 589

Mitchell, J. G., Jones, E. J. W. \& Jones, G. T. The composition and age of basalts dredged from the Blackstones igneous ceritre, western Scotland, 525

Moon, Volcanoes (R), 583

Moose River Basin, Ontario (R), 588

Mount Etna, 357

Mull, 389

Mullite, 497

Nami, M. An exhumed Jurassic meander belt from Yorkshire, England, 47

Natural Catastrophes (R), 91

New Zealand, Geology (R), 87; Greville Formation, 39; northernmost, 61

Nodules, Anhydrite, 569

Norfolk, Cromerian, 469

Normapolles pollen (R), 589

Norsk Polarinstitutt. 1976. Årbok 1974 (R), 492

North America, Ordovician corals, 457

North Cape, New Zealand, 61

Norway, North, 169

Nyctopora, 457 
Oceanography, Arctic Seas (R), 85; Physical and Biological (R), 397

O'Connor, P. J. Strontium isotope ratios of some acid rocks from Mull and Arran, Scotland, 389

Oil finders (R), 181

Oman Mountains (R), 582

Ontario, Upper Silurian? to middle Devonian spores $(\mathrm{R}), 588$

Ordovician, Bryozoan, 515; central Wales, 159; corals, 457; Greenland, 29;

North Portugal, 11; N.W. Spain, 349; Trilobites (R), 184

Ore Deposits (R), 393

Palaeomagnetism, 365

Paleogeography, Porcupine Plateau (R), 179

Paleozoic, Lower (R), 396

Palynomorphs, Preservation and abundance, 233

Paul, C. R. C. Ordovician echinoderms from Greenland, 29

The Peak District (R), 586

Pebble lineation, 141

Periglacial Geomorphology (R), 580

Permian, 401

Petrogenesis (R), 90

Petroleum, geology (R), 491; history of exploration (R), 181

Pettigrew, T. H. \& Suárez, M. An Upper Mesozoic island-arc-back-arc system in the southern Andes and South Georgia, 305

Pickerill, R. K. Vermiforichnus borings from the Ordovician of central Wales, 159

Pickton, C. A. G., Smith, D. G., Harland, W. B. \& Hughes, N. F. The geology of Kong Karls Land, Svalbard, 193

Pidgeon, R. T., Bowes, D. R. \& Hopgood, A. M. Source ages of zircons in an Archaean quartzite, Rona, Inner Hebrides, Scotland, 545

Placoparia (Coplacoparia) borni, 11 ; tournemini, 11

Placoparia (Placoparia) cambriensis, 11

Pleistocene, British, 241

Plimer, I. R. Garnet-biotite relationships in high grade metamorphic rocks at Broken Hill, Australia, 263

Pluton, emplacement of, 553

Porcupine Plateau (R), 179

Porphyroblasts, syntectonic, 383

Porsangerfjord Group, 169

Portugal, North, 11

Potassium-argon, 329

Precambrian, 449; north Norway, 169

Punjab Himalaya, 141

Pyroclastic, flow deposits, 357; post-eruptive sorting, 429

Quaternary, Shark Bay (R), 83

Radioelement concentrations, 271

Reid, R. E. H. Late Cretaceous climatic trends, faunas, and hydrography in Britain and Ireland, 115 
Retiolitids, 277

Rhadinocythere, 489

Rift valleys, 561

Roberts, D. E. Cleavage formation in the Skiddaw Slates of the Northern Lake District, England, 377

Roberts Mountains Formation, Central Nevada (R), 85

Rock, N. M. S. The role of $\mathrm{CO}_{2}$ in alkali rock genesis, 97

Rocky Mountain Main Ranges (R), 587

Romano, M. The trilobite genus Placoparia from the Ordovician of the Valongo area, North Portugal, 11

Roobal, M. J. Post-eruptive mechanical sorting of pyloclastic material - An example from Jamaica, 429

Ross, J. R. P., Maw, U Ba, San, U Bo \& Ciochon, R. L. The Ordovician Bryozoan (Ectoproct) Diplotrypa from Central Burma, 515

Salz, Gebirgemechanik (R), 393

Sandstones, 341

San, U Bo, Maw, U Ba, Ross, J. R. P. \& Ciochon, R. L. The Ordovician Bryozoan (Ectoproct) Diplotrypa from Central Burrna, 515

Sardinia (R), 587

Scientific Enquiry (R), 392

Scotland, Archaean quartzite, 545; basalts, 525; Islay, 2.51

Scrutton, C. T., Horsfield, W. T. \& Harland, W. B. Silurian fossils from western Spitsbergen, 519

Sedimentary Rocks (R), 86

Sedimentation Models (R), 298

Sedimentology, Introduction (R), 491

Sediments (R), 86; Coarse-grained (R), 180

Shark Bay, Quaternary (R), 83

Shotton,F.W. Amplification of the Wolstonian Stage of the British Pleistocene, 241

Sicily, 357

Sillimanite, 497

Silurian, Central Nevada (R), 85; Great Basin (R), 177; western Spitsbergen, 519

Skiddaw Slates, 377

Smith, D. G., Harland, W. B., Hughes, N. F. \& Pickton, C. A. G. The Geology of Kong Karls Land, Svalbard, 193

Smith, D. G., Hughes, N. F. \& Harland, W. B. Preservation and abundance of palynomorphs in Svalbard, 233

South Wales, Coal Measures, 535

Spain, Ordovician, 349; Tertiary, 341

Spinosa, C., Furnish, W. M., Glenister, B. F., Kummel, B., Sweet, W. \& Teichert, C. Reinterpretation of ceratitic ammonoids from the Greville Formation, New Zealand, 39

Spitsbergen, Ordovician (R), 184; western, 519

Spores, Upper Silurian? to middle Devonian (R), 588

Stratigraphy, Quantitative (R), 298

Strontium isotope ratios, 389 
Stuart, A. J. \& West, R. G. Late Cromerian Fauna and Flora at Ostend Norfolk, 469

Suárez, M. \& Pettigrew, T. H. An Upper Mesozoic island-arc-back-arc system in the southern Andes and South Georgia, 305

Svalbard, Kong Karls Land, 193; palynomorphs, 233

Sweet, W., Furnish, W. M., Glenister, B. F., Kummel, B., Spinosa, C. \& Teichert, C. Reinterpretation of ceratitic ammonoids from the Greville Formation New Zealand, 39

Tammemagi, H. Y. Radioelement concentrations in British Tertiary Granites, 271

Tandon, S. K. \& Thakur, V. C. Significance of pebble and mineral lineation in the Chamba syncline of Punjab Himalaya, Himachal Pradesh, India, 141

Tanganyika shield, 53

Tarling, D. H., Turner, P., Archer, R. \& Donovan, R. N. A palaeomagnetic argument concerning post-Devonian displacement along the Great Glen Fault, 365

Tectonic Evolution, Northern Apennines (R), 587; U.S.A. (R), 184

Teichert, C., Furnish, W. M., Glenister, B. F., Kummel, B., Spinosa, \& C. Sweet, W. Reinterpretation of ceratitic ammonoids from the Greville Formation, New Zealand, 39

Tertiary, Faunas (R), 182; Granites, 271 ; sandstones, 341 ; sediments, 441

Thakur, V. C. \& Tandon, S. K. Significance of pebble and mineral lineation in the Chamba syncline of Punjab Himalaya, Himachal Pradesh, India, 141

Time Table, Geological (R), 182

Trace Element (R), 393

Triassic, Bristol District, 569

Trilobita (R), 581

Trilobites (R), 184; Ordovician (R), 184; traces, 349

Trilobitoidea (R), 581

Troodos Lavas, 165

Tucker, M. E. Quartz replaced anhydrite nodules ('Bristol Diamonds') from the Triassic of the Bristol District, 569

Turner, P., Tarling, D. H., Archer, R. \& Donovan, R. N. A palaeomagnetic argument concerning post-Devonian displacement along the Great Glen Fault, 365

Ultramafic complex, New Zealand, 61

Unstable Ground (R), 182

Valongo area, 11

Variation diagram, 371

Vermiforichnus borings, 159

Volcanoes (R), 583

Wales, central, 159

Waterhouse, J. B. \& Bonham-Carter, G. Range, proportionate representation, and demise of brachiopod families through Permian Period, 401 
xviii

Index

Weaver, J. D. Seismically-induced load structures in the basal Coal Measures, South Wales, 535

Western Australia, 129

Western Hemisphere, Earth Sciences (R), 493

West, R. G. \& Stuart, A. J. Late Cromerian Fauna and Flora at Ostend, Norfolk, 469

Williams, D. M. Clastic dykes from the Precambrian Porsangerfjord Group, North Norway, 169

Williams, H. R. An erosional structure in a layered dolerite dyke, West Greenland, 77

Wolstonian Stage, 241

Yorkshire, Jurassic, 47

Zircons, 545 


\section{NOTES FOR GONTRIBUTORS}

Contributions for publication should be addressed to The Editors, Geological Magazine, Sedgwick Museum, Downing Street, Cambridge, CB2 3EQ, England.

All contributions, whether articles, correspondence or reviews, must be typed in duplicate on one side of the paper, double spaced throughout, with a wide margin on the left of each page and a narrower margin on the right. Any minor corrections should be made neatly in the typescript, leaving the margins clear.

The total length of a paper should not in general exceed 20 pages of the Geological Magazine; preference and priority are given to short papers. Longer papers (between 20 and 40 pages of Geological Magazine) will from time to time be considered, but authors wishing to submit such manuscripts should first request further details.

The accuracy of references is the responsibility of authors. References must be double spaced and abbreviated in the form of the World List of Scientific Periodicals 4th Edition as far as possible, e.g. Lapworth, C. 1878. The Moffat Series. Q. Fl geol. Soc., Lond. 34, 240-343. Books should be cited briefly as: Burns, R. G. 1970. Mineralogical applications of crystal field theory. 224 p., C.U.P., London. Unpublished work, e.g. from theses, should normally be referred to in the text in parentheses and not included in the reference list unless in the press.

Articles must be accompanied by a brief summary. Contributions should follow the general style of papers in recent issues of the Magazine and the principles laid down in Notes to Authors (Proc. Geol. Soc. Lond., No. 1627. Oct. 1965). Headings should be set out clearly, but not underlined. Primary headings should be in lower case, at margin, with arabic numeral; sub-headings should be numbered 2.a, 2.b, etc., and tertiary headings 2.a.1., 2.a.2. No cross references should be given by page number, but 'above' and 'below' should be used with the section specified, e.g. Section 2.a.1.

Illustrations must be drawn to allow reduction to maximum size of $165 \mathrm{~mm} \times 110 \mathrm{~mm}$; originals must not exceed $495 \mathrm{~mm} \times 330 \mathrm{~mm}$ and must be sent in a flat package. Lettering must allow for legibility after reduction (i.e. equivalent to $\mathrm{I} \mathrm{mm}$ as a minimum on reduction). Duplicates of illustrations may be prints or, preferably, reductions. Metric units of the SI system are preferred. Illustrations in the text will be referred to as figures (Fig. 2, 2a, etc.), and halftone plates will be referred to (also in arabic) as Plates 2, $2 a$, etc. Folding plates will not be accepted. Captions for figures and plates must be typed on separate sheets.

Twenty-five offprints of each paper will be provided free of charge. Additional offprints may be purchased according to a set scale of charges. 


\section{Geological Magazine}

\section{Volume 113, Number 6, November 1976}

CAMERON, W. E.

$497-514$

Coexisting sillimanite and mullite

$515-518$

U BA MAW, U BO SAN, ROSS, J. R. P. \& CIOCHON, R. L.

The Ordovician Bryozoan (Ectoproct) Diplotrypa from Central Burma

SGRUTTON, C. T., HORSFIELD, W. T. \& HARLAND, W. B.

Silurian fossils from western Spitsbergen

MITCHELL, J. G., JONES, E. J. W. \& JONES, G. T.

The composition and age of basalts dredged from the Blackstones igneous centre, western Scotland

WEAVER, J. D.

$535-543$

Seismically-induced load structures in the basal Coal Measures,

South Wales

BOWES, D. R., HOPGOOD, A. M. \& PIDGEON, R. T.

Source ages of zircons in an Archaean quartzite, Rona, Inner

Hebrides, Scotland

LEITCH, E. C.

Emplacement of an epizonal granodiorite pluton $\lambda$ by vertical block

elevation

FREUND, R. \& MERZER, A. M.

The formation of rift valleys and their zigzag fault patterns

TUCKER, M. E.

Quartz replaced anhydrite nodules ('Bristol Diamonds')

from the Triassic of the Bristol District

MAcRAE, N. D., GRANT, M. \& KULLERUD, G.

A note on the sulphurization of Fe-Tremolite

REVIEWS

$579-590$

PUBLICATIONS RECEIVED

(C) Cambridge University Press 1976

Printed in Great Britain at the University Printing House, Cambridge 